Al-Manhaj: Jurnal Hukum dan Pranata Sosial Islam

Vol. : : 2 (1), 2020, 1-24

P-ISSN : 2686-1607

E-ISSN : 2686-4819

\title{
NALAR KRITIS PELANGGARAN HAK CIPTA DALAM ISLAM
}

\author{
Fitra Rizal \\ Institut Agama Islam Sunan Giri Ponorogo \\ email: fitrajal@gmail.com
}

\begin{abstract}
Copyright infringement is the use or adverse action done by another party to the creator or copyright holder. This study aims to discuss critically how Islam views infringement in copyright. This research uses a qualitative research methodology using a descriptive-interpretative library research approach. The results showed that in the concept of religion and the State all forms of use of property rights of others without the permission of the official owner is a crime and sin. Such is the case in the case of copyright infringement. Copyright infringement in Islam is strictly prohibited because of the element of deception, is another form of theft, kills the creativity and the spirit of thinking of the inventors of the work, and violates the goal of Islamic law which is to damage the mind.
\end{abstract}

Keywords: Infringement, Copyright, Islam

Abstrak: Pelanggaran hak cipta merupakan pemanfaatan atau dan tindakan merugikan yang dilakukan pihak lain terhadap pencipta atau pemegang hak cipta. Penelitian ini bertujuan untuk membahas secara kritis bagaimana Islam memandang pelanggaran dalam hak cipta. Penelitian ini menggunakan metodologi penelitian kualitatif dengan menggunakan pendekatan kepustakaan (library research) deskriptifinterpretatif. Hasil penelitian menunjukkan bahwa dalam konsep agama dan Negara segala bentuk penggunaan hak milik orang lain tanpa seizin pemilik resmi merupakan sebuah kejahatan dan dosa. Hal tersebut seperti yang terjadi dalam kasus pelanggaran hak cipta. Pelanggaran hak cipta dalam Islam sangat dilarang karena adanya unsur pembohongan, merupakan bentuk lain dari tindakan pencurian, membunuh kreatifitas dan semangat berfikir para penemu karya, dan melanggar tujuan syariat Islam yaitu merusak akal (hasil karya).

Kata Kunci: Pelanggaran, Hak Cipta, Islam 


\section{PENDAHULUAN}

Indonesia dikenal sebagai salah satu 'surga' peredaran barang-barang bajakan dan ilegal. Segala barang bajakan dan tiruan dapat ditemukan dengan mudah di negeri ini. Di banyak pusat perniagaan aneka produk bajakan alias palsu seperti: barang elektronik, buku, kaset musik, film, software, hingga obat palsu sekalipun dijual bebas. Tak heran, jika Indonesia pada 2007 tercatat berada di urutan lima besar negara dengan tingkat pembajakan dan pelanggar terbesar hak atas kekayaan intelektual (HAKI). Potensi kerugian dari praktik tersebut sangatlah besar. Untuk produk software (perangkat lunak) saja, potensi penghasilan yang raib mencapai 544 juta dolar AS per tahun. ${ }^{1}$

Hak cipta muncul sebagai bagian yang tak terpisahkan dari hak kekayaan intelektual yang bergerak di bidang seni, sastra dan ilmu pengetahuan. Hal tersebut dimunculkan untuk mendorong kreativitas pencipta sehingga diharapkan mampu mendorong pertumbuhan ekonomi dan kesejahteraan umum. ${ }^{2}$ Harus diketahui bahwa hak kekayaan intelektual merupakan satu bentuk hasil berfikir manusia yang kemudian dijelmakan kedalam sebuah ciptaan atau temuan. Kemudian hak kekayaan intelektual dibagi menjadi dua cabang yaitu hak cipta dan hak kekayaan industri. ${ }^{3}$

Hak cipta adalah hak eksklusif pencipta yang timbul secara otomatis berdasarkan prinsip deklaratif setelah suatu ciptaan

1 Yusuf Assidiq, "Inilah Hukum tentang Hak Cipta dalam Islam", www.republika.co.id, 2012.

2 Arif Lutviansori, Hak Cipta dan Perlindungan Folklore di Dindonesia, (Yogyakarta: Graha Ilmu, 2010), 59.

${ }^{3}$ Arif Lutviansori, 43 -66. 
diwujudkan dalam bentuk nyata tanpa mengurangi pembatasan sesuai dengan ketentuan peraturan perundang-undangan. ${ }^{4}$ Adapun yang dimaksud dengan "hak eksklusif' adalah hak yang hanya diperuntukkan bagi pencipta, sehingga tidak ada pihak lain yang dapat memanfaatkan hak tersebut tanpa izin pencipta. ${ }^{5}$ Dari penjelasan tersebut jelas bahwa hak cipta diperoleh dengan pengorbanan dan perjuangan keras lewat kegiatan-kegiatan kreatif, inovatif dan kemampuan daya pikir atau intelektual pencipta itu sendiri.

Sehingga wajar ketika sesuatu yang berharga dan bernilai kemudian dilakukan upaya perlindungan untuk menjaga dari campur tangan pihak lain yang dapat merugikan pihak yang secara sah menjadi pemilik atas hak cipta tersebut. Sehingga pihak lain yang ingin menggunakannya wajib mendapatkan izin resmi dari pemegang hak cipta yang bersangkutan. ${ }^{6}$ Dari kerangka berfikir di atas maka secara umum segala bentuk pemanfaatan suatu ciptaan yang berhak cipta harus meminta izin resmi kepada pihak yang bersangkutan terlebih dahulu dan jika tanpa izin maka perbuatan tersebut masuk dalam kategori pelanggaran hak cipta dan termasuk dalam kejahatan intelektual. Hal ini sesuai dengan ketentuan pasal 9 ayat 2 dan 3 Undang-undang Republik Indonesia Nomor 28 Tahun 2014 Tentang Hak Cipta yang intinya sebagai berikut, setiap orang yang melaksanakan hak ekonomi wajib mendapatkan izin pencipta atau pemegang hak cipta. Dan setiap Pasal 1.

${ }^{4}$ Undang-undang Republik Indonesia Nomor 28 Tahun 2014 tentang Hak Cipta,

5 Penjelasan Undang -undang Republik Indonesia Nomor 28 Tahun 2014 tentang Hak Cipta, Pasal 4.

${ }^{6}$ Arif Lutviansori, Hak Cipta dan Perlindungan Folklore di Indonesia, 71. 
orang yang tanpa izin pencipta atau pemegang hak cipta dilarang melakukan penggandaan secara komersial ciptaan. Lalu bagaimana agama memandang praktik pelanggaran hak cipta tersebut. Berdasarkan latar belakang di atas, maka penelitian ini bertujuan untuk membahas dengan kritis bagaimana Islam memandang pelanggaran tersebut. Penelitian ini menggunakan metodologi penelitian kualitatif dengan menggunakan pendekatan kepustakaan (library research) deskriptif-interpretatif.

\section{HAK CIPTA}

Hak cipta adalah hak eksklusif pencipta yang timbul secara otomatis berdasarkan prinsip deklaratif setelah suatu ciptaan diwujudkan dalam bentuk nyata tanpa mengurangi pembatasan sesuai dengan ketentuan peraturan perundang-undangan. ${ }^{7}$ Adapun yang dimaksud dengan "hak eksklusif' adalah hak yang hanya diperuntukkan bagi pencipta, sehingga tidak ada pihak lain yang dapat memanfaatkan hak tersebut tanpa izin pencipta. ${ }^{8}$ Dari penjelasan tersebut jelas bahwa hak cipta merupakan hak untuk menguasai atau menyalin suatu ciptaan. Dengan kata lain hak cipta merupakan hak monopoli untuk memperbanyak ciptaan yang dimiliki dengan memperhatikan peraturan perundang-undangan yang berlaku. Dengan hak cipta tersebut pemegang hak cipta dapat

\section{Pasal 1.}

7 Undang-undang Republik Indonesia Nomor 28 Tahun 2014 tentang Hak Cipta,

8 Penjelasan Undang-undang Republik Indonesia Nomor 28 Tahun 2014 tentang Hak Cipta, Pasal 4. 
menggandakan ciptaan yang dimiliki dan dapat melarang penggandaan yang tidak sah.

Dalam Islam, Hak cipta dipandang sebagai salah satu ḥuqūq māliyāh (hak kekayaan) yang mendapat perlindungan hukum (ma’sūm) sebagaimana māl (kekayaan). Hak cipta yang mendapat perlindungan hukum tersebut adalah hak cipta atas ciptaan yang tidak bertentangan dengan hukum Islam. Sebagaimana mal, hak cipta dapat dijadikan objek akad (al-ma'qūd 'alaih), baik akad mu'awặhah (pertukaran, komersial), maupun akad tabarru'at (nonkomersial), serta dapat diwakafkan dan diwarisi. Setiap bentuk pelanggaran terhadap hak cipta, terutama pembajakan merupakan kezaliman yang hukumnya adalah haram. ${ }^{9}$

Hak cipta merupakan hak eksklusif yang terdiri atas hak moral dan hak ekonomi. ${ }^{10}$ Hak moral merupakan hak yang melekat secara abadi pada diri pencipta, untuk: (1) Tetap mencantumkan atau tidak mencantumkan namanya pada salinan sehubungan dengan pemakaian ciptaannya untuk umum. (2) Menggunakan nama aliasnya atau samarannya. (3)Mengubah ciptaannya sesuai dengan kepatutan dalam masyarakat. (4)Mengubah judul dan anak judul ciptaan. (5) Mempertahankan haknya dalam hal terjadi distorsi ciptaan, mutilasi ciptaan, modifikasi ciptaan, atau hal yang bersifat merugikan kehormatan diri atau reputasinya.

Adapun yang disebut degan hak ekonomi adalah hak eksklusif pencipta atau pemegang hak cipta untuk mendapatkan manfaat ekonomi atas ciptaan. Pencipta atau pemegang hak cipta

\footnotetext{
${ }^{9}$ Fatwa Majelis Ulama Indonesia, No. 1 Tahum 2003 tentang Hak Cipta. Cipta, pasal 4.

10 Undang-undang Republik Indonesia Nomor 28 Tahun 2014 tentang Hak
} 
memiliki hak ekonomi untuk melakukan: (1) Penerbitan ciptaan. (2) Penggandaan ciptaan dalam segala bentuknya.

Penerjemahan ciptaan. (4) Pengadaplasian, pengaransemenan, pentransformasian ciptaan. (5) Pendistribusian ciptaan atau salinannya. (6) Pertunjukan ciptaan. (7) Pengumuman ciptaan. (8) Komunikasi ciptaan. (9) Penyewaan ciptaan.

\section{CIPTAAN YANG DILINDUNGI}

Ciptaan yang dilindungi meliputi ciptaan dalam bidang ilmu pengetahuan, seni, dan sastra, terdiri atas (1)Buku, pamflet, perwajahan karya tulis yang diterbitkan, dan semua hasil karya tulis lainnya. (2) Ceramah, kuliah, pidato, dan Ciptaan sejenis lainnya. (3) Alat peraga yang dibuat untuk kepentingan pendidikan dan ilmu pengetahuan. (4) Lagu dan/atau musik dengan atau tanpa teks. (5) Drama, drama musikal, tari, koreografi, pewayangan, dan pantomime. (6) Karya seni rupa dalam segala bentuk seperti lukisan, gambar, ukiran, kaligrafi, seni pahat, patung, atau kolase. (7) Karya seni terapan. (8) Karya arsitektur, (9) Peta. (10) Karya seni batik atau seni motif lain. (11) Karya fotografi. (12) Potret. (13) Karya sinematografi. (14) Terjemahan. tafsir, saduran, bunga rampai, basis data, adaptasi, aransemen, modifikasi dan karya lain dari hasil transformasi. 15) Terjemahan, adaptasi, aransemen, transformasi, atau modihkasi ekspresi budaya tradisional. (16) Kompilasi ciptaan atau data, baik dalam format yang dapat dibaca dengan program komputer maupun media lainnya. (17) Kompilasi ekspresi budaya tradisional selama 
kompilasi tersebut merupakan karya yang asli. (18) Permainan video. (19) Program komputer. ${ }^{11}$

Beberapa ciptaan tesebut merupakan contoh dari ciptaan yang dilindungi dalam Undang-undang Hak Cipta 2014, namun bukan berarti ketika ada karya lain di luar yang disebutkan dalam rincian pasal tersebut tidak dapat dilindungi. Karena yang menjadi acuan adalah selama karya tersebut masih dalam koridor seni, sastra dan ilmu pengetahuan, maka dimasukkan dalam perlindungan hak cipta. ${ }^{12}$ Dan perlindungan terhadap hak cipta juga ditujukan untuk semua ciptaan yang yang sudah berbentuk secara nyata dan dapat diperbanyak, tetapi ciptaan tersebut tidak atau belum diumumkan. ${ }^{13}$

\section{CIPTAAN YANG TIDAK MEMILIKI HAK CIPTA}

Ada beberapa ciptaan yang yang tidak memiliki hak cipta, diantaranya adalah sebagai berikut (1) Hasil rapat terbuka lembaga Negara. (2) Peraturan perundang-undangan. (3) Pidato kenegaraan atau pidato pejabat pemerintah. (4) Putusan pengadilan atau penetapan hakim. (5) Kitab suci atau simbol keagamaan. ${ }^{14}$

Ciptaan-ciptaan tersebut tidak ada hak ciptanya karena dibuat untuk kepentingan umum bukan untuk kepentingan

11 Undang-undang Republik Indonesia Nomor 28 Tahun 2014 tentang Hak Cipta, Pasal 40 ayat 1.

12 Arif Lutviansori, Hak Cipta dan Perlindungan Folklore di Dindonesia, 77.

13 Gatot Supramono, Hak Cipta dan Aspek-Aspek Hukumnya (Jakarta: Rineka Cipta, 2010), 10.

14 Undang-undang Republik Indonesia Nomor 28 Tahun 2014 Tentang Hak Cipta, Pasal 42. 
pribadi. ${ }^{15}$ Dengan pertimbangan tersebut, maka setiap orang diperbolehkan memperbanyak ciptaan yang dimaksud dan tidak ada yang melarangnya.

\section{PERALIHAN HAK CIPTA}

Hak cipta merupakan hak yang dapat dimiliki, dapat menjadi objek pemilikan atau hak milik dan oleh karena itu dalam hak cipta berlaku syarat-syarat pemilikan, baik mengenai cara penggunaannya maupun cara pengalihan haknya. ${ }^{16}$ Maka dari itu hak cipta dapat beralih atau dialihkan, baik seluruh maupun sebagian dengan beberapa cara berikut ini (1) Pewarisan, (2) Hibah, (3) Wakaf, (4) Wasiat, (5) Perjanjian tertulis, (6) Sebab lain yang dibenarkan sesuai dengan ketentuan peraturan perundanundangan. ${ }^{17}$

Yang dimaksud dengan "sebab lain yang dibenarkan sesuai dengan ketentuan peraturan perundang-undangan" antara lain, pengalihan yang disebabkan oleh putusan pengadilan yang telah memperoleh kekuatan hukum tetap, merger, akuisisi, atau pembubaran perusahaan atau badan hukum dimana terjadi penggabungan atau pemisahan aset perusahaan. ${ }^{18}$ Peralihan hak cipta tersebut harus dengan akta otentik atau akta dibawah tangan. Hal ini dilakukan untuk kepentingan dokumentasi dan

15 Gatot Supramono, Hak Cipta dan Aspek-aspek Hukumnya, 11.

16 Ok Saidin, Aspek Hukum Hak Kekayaan Intelektual (Jakarta: Raja Grafindo Persada, 2007), 111.

17 Undang -undang Republik Indonesia Nomor 28 Tahun 2014 tentang Hak Cipta, Pasal 16 ayat 2.

18 Penjelasan Undang -undang Republik Indonesia Nomor 28 Tahun 2014 tentang Hak Cipta, Pasal 16 ayat 2. 
untk mencapai kepastian hokum diantara para pihak sehingga tidak ada pihak yang dirugikan dikemudian hari. ${ }^{19}$ Pada intinya adalah sebab beralihnya hak cipta tersebut harus secara resmi sesuai dengan peraturan perundang-undangan lewat putusan pengadilan sehingga diharapkan tidak ada pihak yang dirugikan.

\section{JANGKA WAKTU PERLINDUNGAN HAK CIPTA}

Sebagaimana yang diketahui bahwa, sejak ciptaan diwujudkan maka akan berakibat munculnya hak cipta atas ciptaan tersebut. Hal ini berarti sejak saat itu juga hak cipta mulai berlaku. Pendipta resmi memiliki hak cipta, maka ia berhak mengumumkan maupun memperbanyak ciptaanya dan melarang pihak lain untuk meniru maupun melipat gandakan ciptaanya. ${ }^{20}$ Pembatasan tersebut bertujuan agar dalam setiap penggunaan ciptaan yang berhak cipta harus sesuai dengan ketentuan yang ada, sehingga diharapkan setiap orang atau pihak lain yang ingin menggunakan ciptaan tersebut tidak boleh sewenang-wenang. ${ }^{21}$

Perlindungan hak cipta ini diberikan untuk memberikan kepastian hukum sampai kapan suatu ciptaan dapat dijamin perlindungannya. Adanya jangka waktu perlindungan ini diharapkan mampu memberikan perasaan aman bagi penciptanya untuk dapat terus melakukan kreasi-kreasi dibidang hak cipta. Ketentuan mengenai jangka waktu perlindungan hak cipta, diantaranya adalah sebagai berikut:

19 Yusran Isnaini, Hak cipta dan tantangan di Era Cyber Space (Bogor: Ghalia Indonesia, 2009), 19.

20 Gatot Supramono, Hak Cipta dan Aspek-aspek Hukumnya , 14.

21 Ok Saidin, Aspek HUkum Hak Kekayaan Intelektual, 62. 
Pelindungan Hak Cipta atas Ciptaan: (1) Buku, pamflet, dan semua hasrl karya tulis lainnya. (2) Ceramah, kuliah, pidato, dan Ciptaan sejenis lainnya. (3) Alat peraga yang dibuat untuk kepentingan pendidikan dan ilmu pengetahuan. (4) Lagu atau musik dengan atau tanpa teks. (5) Drama, drama musikal, tari, koreografi, pewayangan, dan pantomime. (6) Karya seni rupa dalam segala bentuk seperti lukisan, gambar, ukiran, kaligrali, seni pahat, patung, atau kolase. (7) Karya arsitektur. (8) Peta. (9) Karya seni batik atau seni motif lain.

Hak cipta dalam karya tersebut berlaku selama hidup pencipta dan terus berlangsung selama 70 (tujuh puluh) tahun setelah pencipta meninggal dunia, terhitung mulai tanggal 1 Januari tahun berikutnya. Dan jika ciptaan tersebut dimiliki oleh 2 (dua) orang atau lebih, maka pelindungan hak cipta berlaku selama hidup Pencipta yang meninggal dunia paling akhir dan berlangsung selama 70 (tujuh puluh) tahun sesudahnya, terhitung mulai tanggal I Januari tahun berikutnya. Akan tetapi jika ciptaan tersebut dimiliki atau dipegang oleh badan hukum, maka perlindungan hak cipta berlaku selama 50 (lima puluh) tahun sejak pertama kali dilakukan pengumuman. ${ }^{22}$

Pelindungan Hak Cipta atas Ciptaan, Hak cipta dalam karya berikut ini berlaku selama 50 (1ima puluh) tahun sejak pertama kali dilakukan Pengumuman. (1) Karya fotografi. (2) Potret. (3) Karya sinematografi. (4) Permainan video. (5) Program computer. 
(6) Perwajahan karya tulis. (7) Terjemahan, tafsir, saduran, bunga rampai, basis data, adaptasi, aransemen, modifikasi dan karya lain dari hasil transformasi. (8) Terjemahan, adaptasi, aransemen, transformasi atau modifikasi ekspresi budaya tradisional. (9) Kompilasi ciptaan atau data, baik dalam format yang dapat dibaca dengan Program Komputer atau media lainnya. (10) Kompilasi ekspresi budaya tradisional selama kompilasi tersebut merupakan karya yang asli. ${ }^{23}$

Dari uraian diatas dapat dipahami bahwa, perlindungan yang diberikan oleh undang-undang terhadap hak cipta adalah untuk menstimulir atau merangsang aktivitas para pencipta agar terus produktif dan kereatif. ${ }^{24}$ Maka dari itu munculnya ciptaan baru atau ciptaan yang sudah ada harus didukunga dan dilindungi oleh kekuatan hukum dari hukum Negara maupun hukum agama.

\section{PELANGGARAN HAK CIPTA}

Bentuk pelanggaran hak cipta bisa bermacam-macam, misalnya pembajakan. Berdasarkan UU Nomor 19 Tahun 2002, dapat dilihat bahwa unsur-unsur yang termasuk pelanggaran dalam kategori pelanggaran adalah barangsiapa dengan sengaja dan tanpa hak melakukan perbuatan menyiarkan, memamerkan, mengedarkan, menjual memperbanyak penggunaan citptaan yang berhak cipta dengan tujuan untuk kepentingan komersial maka

23 Undang -undang Republik Indonesia Nomor 28 Tahun 2014 tentang Hak Cipta, Pasal 58 ayat 1.

24 Ok Saidin, Aspek Hukum Hak Kekayaan Intelektual, 112. 
termasuk dalam pelanggaran hak cipta. ${ }^{25}$ Selanjutnya ditegaskan dalam UU Nomor 28 Tahun 2014, menyatakan bahwa yang termasuk dengan pelanggaran hak cipta adalah setiap orang atau lembaga yang dengan tanpa hak atau tanpa izin pencipta atau pemegang hak cipta melakukan pelanggaran hak ekonomi. ${ }^{26}$ Intinya yang disebut dengan pelanggaran hak cipta adalah adanya pemanfaatan atau dan tindakan merugikan yang dilakukan pihak lain terhadap pencipta atau pemegang hak cipta. Berikut ini beberapa contoh bentuk pelanggaran hak cipta yang terjadi disekitar kita diantaranya adalah pembajakan lagu, video, film dan buku.

\section{ETIKA DALAM MENGGUNAKAN HAK CIPTA}

Penggunaan, pengambilan, penggandaan, dan/atau pengubahan suatu ciptaan secara seluruh atau sebagian yang substansial tidak dianggap sebagai pelanggaran hak cipta jika sumbernya disebutkan atau dicantumkan secara lengkap untuk keperluan:27 (1) Pendidikan, penelitian, penulisan karya ilmiah, penyusunan laporan, penulisan kritik atau tinjauan suatu masalah dengan tidak merugikan kepentingan yang wajar dari pencipta atau pemegang hak cipta. (2) Keamanan serta penyelenggaraan pemerintahan, legislatif, dan peradilan. (3) Ceramah yang hanya

25 Undang-undang Republik Indonesia Nomor 19 Tahun 2002 tentang Hak Cipta, Pasal 72 dan 73 .

26 Undang-undang Republik Indonesia Nomor 28 Tahun 2014 tentang Hak Cipta, Pasal 112 - 119.

27 Undang-undang Republik Indonesia Nomor 19 Tahun 2002 tentang Hak Cipta, Pasal 44 ayat 1 . 
untuk tujuan pendidikan dan ilmu pengetahuan. (4) Pertunjukan atau pementasan yang tidak dipungut bayaran dengan ketentuan tidak merugikan kepentingan yang wajar dari pencipta. ${ }^{28}$

Berdasarkan UU Nomor 28 Tahun 2014, menjelaskan bahwa yang intinya setiap pihak yang ingin memanfaatkan ciptaan yang berhak cipta, maka wajib mendapatkan izin dari pencipta atau pemegang hak cipta. Maka siapapun yang tanpa izin dari pencipta atau pemegang hak cipta dilarang melakukan penggandaan atau pemanfaatan ciptaan tersebut. Akan tetapi hal tersebut tidak disebut melanggar hak cipta jika sumbernya dicantumkan secara lengkap dengan ketentuan yang telah disebutkan diatas. Jadi etika yang harus diperhatikan dalam menggunakan ciptaan yang berhak cipta di antaranya adalah harus memiliki izin resmi dari pencipta dan atau pemegang hak cipta. Dan jika tidak maka harus menyantumkan sumbernya secara lengkap dengan ketentuan yang telah disebutkan diatas.

\section{PANDANGAN ULAMA TENTANG HAK CIPTA}

Mayoritas ulama dari kalangan mazhab Maliki, Syafi'i dan Hanbali berpendapat bahwa hak cipta atas ciptaan yang orsinal dan memiliki manfaat termasuk dalam harta berharga dan boleh dimanfaatkan dengan cara yang benar. Berkenaan dengan hak kepengarangan (haqq al-ta'lif), salah satu hak cipta, Wahbah alZuhaili menegaskan, bahwa hak kepengarangan adalah hak yang dilindungi oleh syara'(hukum Islam) atas dasar qaidah istishlah 
(maslahah mursalah), mencetak ulang atau mengcopy buku (tanpa izin yang sah) dipandang sebagai pelanggaran atau kejahatan terhadap hak pengarang; dalam arti bahwa perbuatan tersebut adalah kemaksiatan yang menimbulkan dosa dalam pandangan Syara' dan merupakan pencurian yang mengharuskan ganti rugi terhadap hak pengarang atas naskah yang dicetak secara melanggar dan zalim, serta menimbulkan kerugian moril yang menimpanya. ${ }^{29}$ Penjelasan diatas menunjukkan bahwa hak cipta merupakan bagian dari hak kekayaan yang harus dijaga dan dilindungi secara hukum. Dan segala bentuk pelanggaran hak cipta harus dihindari dan dihilangkan karena dapat merugikan pihak yang terkait.

\section{FATWA MUI TENTANG PERLINDUNGAN HAK KEKAYAAN INTELEKTUAL}

Putusan fatwa MUI No. 1/MUNAS VII/MUI/5/2005 Tentang Perlindungan Hak Kekayaan Intelektual (HKI) adalah sebagi berikut: ${ }^{0}$ (1) Dalam hukum Islam, HKI dipandang sebagai salah

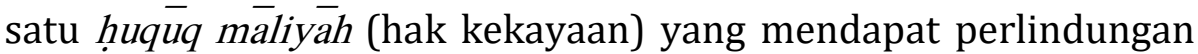
hukum (ma'șum) sebagaimana māl (kekayaan). (2) HKI yang mendapat perlindungan hukum Islam sebagaimana dimaksud adalah HKI yang tidak bertentangan dengan hukum Islam. (3) HKI dapat dijadikan objek akad (al-ma'qūd 'alaih), baik akad mu'awad\}ah (pertukaran, komersial), maupun akad tabarru'at

\footnotetext{
${ }^{29}$ Fatwa Majelis Ulama Indonesia, No. 1 Tahum 2003 Tentang Hak Cipta.

30 Fatwa Majelis Ulama Indonesia No. 1/MUNAS VII/MUI/5/2005 Tentang Perlindungan Hak Kekayaan Intelektual (HKI).
} 
(nonkomersial), serta dapat diwakafkan dan diwarisi. (4) Setiap bentuk pelanggaran terhadap HKI, menggunakan, mengungkapkan, membuat, memakai, menjual, mengimpor, mengekspor, mengedarkan, menyerahkan, menyediakan, mengumumkan, memperbanyak, menjiplak, memalsu, membajak HKI milik orang lain secara tanpa hak merupakan kezaliman dan hukumnya adalah haram.

Putusan fatwa MUI Nomor 1 Tahun 2003 Tentang Hak Cipta adalah sebagai berikut: (1) Dalam hukum Islam, Hak cipta dipandang sebagai salah satu ḥuqūq măliyāh (hak kekayaan) yang mendapat perlindungan hukum (ma’șüm) sebagaimana màl (kekayaan). (2) Hak cipta yang mendapat perlindungan hukum Islam sebagaimana dimaksud adalah hak cipta atas ciptaan yang tidak bertentangan dengan hukum Islam. (3) Sebagaimana māl, hak cipta dapat dijadikan objek akad (al-ma'qūd 'alaih), baik akad mu'awad\}ah (pertukaran, komersial), maupun akad tabarru'at (nonkomersial), serta dapat diwakafkan dan diwarisi. (4) Setiap bentuk pelanggaran terhadap hak cipta, terutama pembajakan merupakan kezaliman yang hukumnya adalah haram. ${ }^{31}$

\section{PELANGGARAN HAK CIPTA DALAM ISLAM}

Bentuk pelanggaran hak cipta bisa bermacam-macam, misalnya pembajakan. Berdasarkan UU Nomor 19 Tahun 2002, dapat dilihat bahwa unsure-unsur yang termasuk pelanggaran dalam kategori pelanggaran adalah barangsiapa dengan sengaja dan tanpa hak melakukan perbuatan menyiarkan, memamerkan,

31 Fatwa Majelis Ulama Indonesia, No. 1 Tahum 2003 tentang Hak Cipta. 
mengedarkan, menjual memperbanyak penggunaan citptaan yang berhak cipta dengan tujuan untuk kepentingan komersial maka termasuk dalam pelanggaran hak cipta. ${ }^{32}$ Selanjutnya ditegaskan dalam UU Nomor 28 Tahun 2014, menyatakan bahwa yang termasuk dengan pelanggaran hak cipta adalah orang atau lembaga yang dengan tanpa hak atau tanpa izin pencipta atau pemegang hak cipta melakukan pelanggaran hak ekonomi. ${ }^{33}$ Intinya yang disebut dengan pelanggaran hak cipta adalah adanya pemanfaatan atau dan tindakan merugikan yang dilakukan pihak lain terhadap pencipta atau pemegang hak cipta. Maka dari itu setiap pihak yang ingin memanfaatkan ciptaan yang berhak cipta, maka wajib mendapatkan izin dari pencipta atau pemegang hak cipta. Dan jika tanpa izin tersebut maka pihak yang bersangkutan dilarang melakukan penggandaan atau pemanfaatan ciptaan tersebut. Karena tindakan tersebut ilegal dan dapat merugikan pihak yang terkait.

Dalam pandangan MUI, praktik pelanggaran hak cipta sudah mencapai tahap yang meresahkan. Banyak pihak dirugikan, terutama pemegang hak cipta, negara dan masyarakat. ${ }^{34}$ Maka segala bentuk pelanggaran hak cipta harus dihilangkan dan hukumnya haram karena dinilai telah melanggar hukum Negara dan hukum agama. Hal tersebut sesui dengam ketentuan Fatwa Majelis Ulama Indonesia, No. 1 Tahum 2003 Tentang Hak Cipta,

32 Undang-undang Republik Indonesia Nomor 19 Tahun 2002 tentang Hak Cipta, Pasal 72 dan 73.

33 Undang-undang Republik Indonesia Nomor 28 Tahun 2014 tentang Hak Cipta, Pasal 112 - 119.

34 Fatwa Majelis Ulama Indonesia, No. 1 Tahum 2003 tentang Hak Cipta. 
Fatwa Majelis Ulama Indonesia, No. 1/MUNAS VII/MUI/5/2005 Tentang Perlindungan Hak Kekayaan Intelektual (HKI) dan Undang-undang Republik Indonesia Nomor 28 Tahun 2014 Tentang Hak Cipta.

Larangan tersebut didasarkan atas petunjuk al-Quran, alHadis, qawaid fiqh dan pendapat beberapa ulama yang intinya adalah bahwa segala bentuk kejahatan, kerusakan, kebatilan harus dihindari dan hukumnya haram. Untuk lebih memahami perhatikan penjelasan berikut ini:

1. Dalil Dari Al-Quran

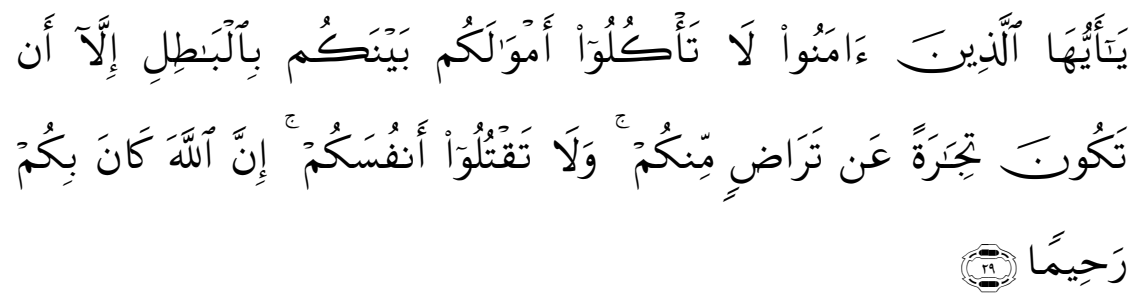

Artinya :

Hai orang-orang yang beriman, janganlah kamu saling memakan harta sesamamu dengan jalan yang batil, kecuali dengan jalan perniagaan yang Berlaku dengan suka sama-suka di antara kamu. dan janganlah kamu membunuh dirimu. Sesungguhnya Allah adalah Maha Penyayang kepadamu. (QS. an-Nisa': 29)

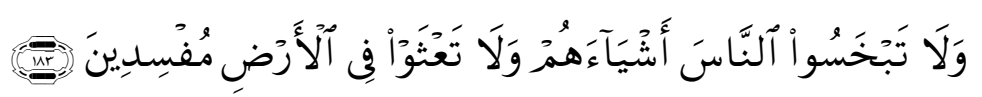

Artinya:

Dan janganlah kamu merugikan manusia pada hak-haknya dan janganlah kamu merajalela di muka bumi dengan membuat kerusakan. (QS. Al-Syu'ara: 183). 
Kedua ayat diatas secara tegas melarang kita memakan harta orang lain secara batil (tanpa hak), melarang berbuat zalim dan tidak boleh merugikan orang lain dengan cara apapun. Maka segala bentuk perbuatan yang merugikan pihak lain dilarang dalam Islam dan hukumnya haram. Dengan demikin sudah jelas bahwa segala bentuk pelanggaran hak cipta merupakan bentuk kejahatan yang sangat merugiakan dan hukumnya haram. Oleh karena itu pelanggaran tersebut harus dihilangkan.

2. Dalil Dari Al-Hadis

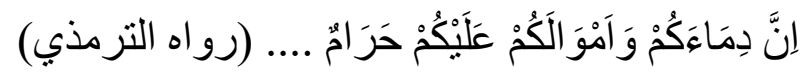

Artinya:

Sesungguhnya darah (jiwa) dan hartamu adalah haram (dilindungi) ... (HR. al-Tirmizi).

$$
\text { لَا ضَرَرَ وَلَاضِرَارَ .... (رو اهِ ابن ماجها) }
$$

Artinya:

Tidak boleh membahayakan (merugikan) diri sendiri dan tidak boleh membayakan (merugiakan orang lain) ... (HR. Ibnu Majah).

Dari hadis diatas jelas bahwa Rasulullah SAW sangat mencela segala tindakan yang bisa merugikan hak orang lain. Sehingga pelanggaran hak cipta harus dihilangkan karena hal tersebut masuk dalam perbutan yang merugikan dan hukumnya haram. 
3. Dalil Dari Qawa'id Fiqh

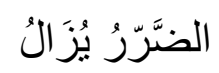

Artinya :

Bahaya (kerugian) harus dihilangkan.

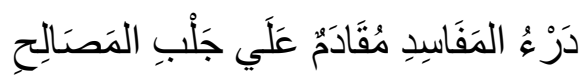

Artinya :

Menghilangkan mafsadah didahulukan atas mendatangkan maslahah.

Maksud dari kaidah diatas adalah suatu kerusakan atau kemafsadatan harus dihilangkan karena kerusakan tidak dibolehkan dalam Islam. ${ }^{35}$ Seperti pada kasus pelanggaran hak cipta, seseorang ingin mengambil manfaat dari suatu ciptaan yang berhak cipta tanpa izin resmi, yang berakibat pada tindakan kejahatan dan merugikan. Sehingga hal tersebut harus dihilangkan dan dihindari karena hukumnya haram.

4. Pandangan Ulama

Wahbah al-Zuhaili menegaskan, bahwa hak kepengarangan adalah hak yang dilindungi oleh syara'(hukum Islam) atas dasar qaidah istishlah tersebut, mencetak ulang atau mengcopy buku (tanpa izin yang sah) dipandang sebagai pelanggaran atau kejahatan terhadap hak pengarang; dalam arti bahwa perbuatan tersebut adalah kemaksiatan yang menimbulkan dosa dalam pandangan syara' dan merupakan pencurian yang mengharuskan ganti rugi terhadap hak pengarang atas naskah yang dicetak secara

35 Hasbiyaallah, Fiqh dan Ushul Fiqh (Bandung: Remaja Rosdakarya, 2013), 136137. 
melanggar dan zalim, serta menimbulkan kerugian moril yang menimpanya. ${ }^{36}$ Penjelasan tersebut menunjukkan bahwa pelanggaran hak cipta merupakan bagian dari bentuk kejahatan yang merugikan pihak pencipta dan atau pemegang hak cipta. terhadap hak pengarang. Maka dari itu perbuatan tersebut dipandang sebagai perbutan yang haram sehingga harus dihindari dan dihilangkan.

Setelah memerhatikan seluruh aspek diatas, maka dapat disimpulkan bahwa hak cipta harus mendapatkan perlindungan hukum dari Negara maupun agama. Dan segala bentuk pelanggaran hak cipta merupakan tindakan kejahatan yang sangat merugikan sehingga harus dihindari dan dihilangkan. Islam secara tegas mengakui dan melindungi hak cipta serta memandang segala bentuk pelanggaran atas hak cipta adalah sebuah kejahatan yang harus dihindari dan dihilangkan.

\section{NALAR KRITIS PELANGGARAN HAK CIPTA DALAM ISLAM}

Sekarang mari kita coba memahami tentang hak cipta dan adanya pelanggaran hak cipta. Karya yang merupakan hasil usaha dan pemikiran dari seseorang, maka secara otomatis karya tersebut merupakan hak milik orang yang menciptakannya. Ketika karya tersebut jelas milik seseorang maka orang lain tidak punya hak untuk memiliki atau menggunakan tanpa seizin pemilik.

Dalam konsep agama dan Negara segala bentuk penggunaan hak milik orang lain tanpa seizin pemilik resmi 
merupakan sebuah kejahatan dan dosa. Ketika seseorang yang menggunakan hak tersebut tanpa izin resmi berarti dia telah memakai hak milik orang lain dan termasuk dalam bentuk kejahatan. Walaupun niat atau tujuannya baik akan tetapi cara untuk memperolehnya salah atau tanpa prosedur yang benar, maka tujuan yang semula baik menurut kaca pandang empiris menjadi buruk dan dosa dalam kaca pandang hakiki. Hal tersebut sesuai dengan kaidah usul fiqh yang intinya adalah status hukum dapat berubah berdasarkan latar belang yang mendasarinya.

Poin yang menjadi alasan terkait pengharaman dalam pelanggaran hak cipta diantaranya adalah (1) Adanya unsur pembohongan. (2) Merupakan bentuk pencurian. (3) Membunuh kreatifitas dan semangat berfikir para penemu karya. (4) Melanggar tujuan syariat yaitu merusak akal (hasil karya).

Seharusnya seseorang dalam menggunakan karya milik orang lain mempunyai niat untuk memperkuat keilmuan yang telah ada dan berusaha menemukan karya yang baru. Melahirkan gagasan baru berdasarkan karya (gagasan) yang lama dengan menunjukkan secara jujur karya yang mempengaruhi pemikirannya. Sehingga disana terjadi dialektika yang jujur, jujur pada diri sendiri maupun pihak lain. Dan hal tersebut bukan merupakan tindak pencurian serta disana terjadi pengakuan dan penghormatan kepada pemilik karya acuan (karya yang lama). Dengan adanya hal tersebut maka meningkatkan kreatifitas dan meningkatkan semangat berfikir (menjaga akal). Seorang ilmuan dan pemikir harus "jentel" mengakui jika karya yang dia dunakan atau dia hasilkan ada sumbangsih dari karya (gagasan) terdahulu. 


\section{KESIMPULAN}

Pelanggaran hak cipta adalah adanya pemanfaatan atau dan tindakan merugikan yang dilakukan pihak lain terhadap pencipta atau pemegang hak cipta. Berdasarkan UU Nomor 28 Tahun 2014, menjelaskan bahwa yang intinya setiap pihak yang ingin memanfaatkan ciptaan yang berhak cipta, maka wajib mendapatkan izin dari pencipta atau pemegang hak cipta. Maka siapapun yang tanpa izin dari pencipta atau pemegang hak cipta dilarang melakukan penggandaan atau pemanfaatan ciptaan tersebut. Akan tetapi hal tersebut tidak disebut melanggar hak cipta jika sumbernya dicantumkan secara lengkap dengan ketentuan yang telah disebutkan dalam undang-undang. Jadi etika yang harus diperhatikan dalam menggunakan ciptaan yang berhak cipta diantaranya adalah harus memiliki izin resmi dari pencipta dan atau pemegang hak cipta. Dan jika tidak maka harus menyantumkan sumbernya secara lengkap dengan ketentuan yang telah ditetapkan.

Hak cipta harus mendapatkan perlindungan hukum dari Negara maupun agama. Dan segala bentuk pelanggaran hak cipta merupakan tindakan kejahatan yang sangat merugikan sehingga harus dihindari dan dihilangkan. Islam secara tegas mengakui dan melindungi hak cipta serta memandang segala bentuk pelanggaran atas hak cipta adalah sebuah kejahatan yang harus dihindari dan dihilangkan. Pelanggaran hak cipta dalam Islam sangat dilarang karena adanya unsur pembohongan, merupakan bentuk lain dari 
tindakan pencurian, membunuh kreatifitas dan semangat berfikir para penemu karya, dan melanggar tujuan syariat Islam yaitu merusak akal (hasil karya).

\section{DAFTAR PUSTAKA}

Fatwa Majelis Ulama Indonesia No. 1/MUNAS VII/MUI/5/2005 tentang Perlindungan Hak Kekayaan Intelektual (HKI). Jakarta: Musyawarah Nasional VII MUI, 2005.

Fatwa Majelis Ulama Indonesia. No. 1 Tahum 2003 tentang Hak Cipta. Jakarta: Komisi Fatwa MUI, 2003.

Hasbiyaallah. Fiqh dan Ushul Fiqh. Bandung: Remaja Rosdakarya, 2013.

Lutviansori, Arif. Hak Cipta dan Perlindungan Folklore di Indonesia. Yogyakarta: Graha Ilmu, 2010.

Penjelasan Undang - undang Republik Indonesia Nomor 28 Tahun 2014 tentang Hak Cipta.

Saidin, Ok. Aspek Hokum Hak Kekayaan Intelektual. Jakarta: Raja Grafindo Persada, 2007.

Supramono, Gatot. Hak Cipta dan Aspek-aspek Hukumnya. Jakarta: Rineka Cipta, 2010.

Undang-undang Republik Indonesia Nomor 28 Tahun 2014 tentang Hak Cipta.

Undang-undang Republik Indonesia Nomor 19 Tahun 2002 tentang Hak Cipta.

Assidiq, Yusuf. Inilah Hukum tentang Hak Cipta dalam Islam, republika.co.id. 2012 